http://dx.doi.org/10.18778/7969-353-5.16

Joanna Żeromska-Charlińska*

\title{
Potencjalna gotowość do spotkania w kontekście opieki i pomocy chorym w stanie terminalnym
}

Streszczenie: Problem zaczyna się w momencie, w którym rzeczywistość stawia opór poprzez nieprzewidywalną zmianę sytuacji. Co prawda, zasób wiedzy jest na tyle rozległy, że pozwala na dostosowanie zachowań podmiotu do zmieniającego się kontekstu, jednak w czasie radykalnej, głębokiej zmiany-traumy ów zasób wiedzy staje się niewystarczający.

Fakt spotkania w czasie i przestrzeni z jednej strony odnosi się do dziejącej się tu i teraz rzeczywistości. Interakcja między podmiotami sprowadza się do ułatwiania zrozumienia innego pozytywnego rozwiązania konfliktu i nierównowagi prowadzącego do nowego spojrzenia na rzeczywistość. $Z$ drugiej zaś oscyluje wokół potencjalności moralności spotkania, które w odczuciu podmiotu jest ,inne” niż to, które istnieje w chęciach czy świadomości działającego.

Słowa kluczowe: stan terminalny, spotkanie, doświadczanie, opieka medyczna, senior.

\section{Potential readiness for meeting in the context of care and help served for person in terminal stage}

Summary: Problem is starting to appear in the moment, when reality resists through unpredictable changing of situation. It is true, knowledge resources is so extensive, that make possible to adjust of subject's behaviour to changing context, however during radical, profound changing-trauma, this knowledge resources is becoming insufficient.

The fact of meeting in a space and time relates to reality going on here and now from one side. Whereas interaction among subjects relates on facilitating understanding of other, positive conflict solving and imbalance that leads to new perception of reality. Form other side oscillates around

* Uniwersytet Warmińsko-Mazurski, Wydział Nauk Społecznych, Katedra Pedagogiki Resocjalizacyjnej, 10-561 Olsztyn, ul. Żołnierska 14. 
potentiality of meeting's morality which in the opinion of subject is „different" from the one, that exists in willingness and consciousness of acting individual.

Keywords: end of term state, meeting, experience, health care, senior.

Spotkanie jako wydarzenie na drodze życiowej stanowi szansę wzbogacenia, a zarazem przekraczania własnego doświadczenia. Stanowi świadectwo zgłębiania prawdy o samym sobie. Refleksja nad fenomenem spotkania stanowi swego rodzaju ,nadistotę” w intensywnej współczesności, ostatecznie rozstrzygającą o jakości istnienia człowieka w przestrzeni aksjologiczno-moralnej.

Wydarzenie spotkania, moment zaistnienia spotkania porównywany jest do olśnienia, błysku czy iluminacji, w których to wyraża się jego nagłość i natychmiastowość (Gadacz, 1999; Bukowski, 1987). Spotkania w wymiarze cierpienia stanowią proces, w którym czas kształtuje jego istotę, siłę, którego znaczenie uświadamiane jest długo po zakończeniu. Relacja nieobojętności, odpowiedzialności może stanowić podstawę spotkania $\mathrm{z}$ chorym. Filozofia E. Levinasa dowodzi, że odpowiedzialność stanowi warunek samorealizacji, czyniący człowieka otwartym na innych i ich system wartości (Włodarczyk, 2009, s. 97). E. Levinas (ibidem, s. 244) odnosi modalność bycia wobec Innego do sprawiedliwości, czyli na jednoczesnym byciu $\mathrm{w}$ relacji odpowiedzialności z innymi oraz na wolności wycofania się z relacji. Ignorancja, dystans, wycofanie nie są reakcjami obojętnymi wobec Innego. Krytykuje kulturę immanencji, która w przeciwieństwie do transcendencji „blokuje" niejako nabywanie na nowo siebie w relacji/ponowne bycie obdarowanym (ibidem, s. 304). Spotkanie pozbawione jest reguł i wiąże się z zaskoczeniem. Żadna ekonomia moralna, kalkulacje i spekulacje, dobór osób nie gwarantują przeżycia spotkania. Fundamentem spotkania staje się autentyczna i bezinteresowna postawa otwarcia i chęć budowania relacji dialogu. Celem rozważań uczyniłam fakt rozumienia i przeżycia kategorii spotkania z osobą w stanie choroby terminalnej, a także wgląd w jakość egzystencjalnego znaczenia i realizacji owego spotkania.

Proces rekonstrukcji doświadczeń biograficznych chorej w stanie terminalnym dotyczył rekonstrukcji indywidualnej biografii życiowej seniorki oraz analizy wątków wyodrębnionych w wywiadzie, który to zabieg pozwolił na zaakcentowanie doświadczeń odpowiadających autorefleksji dotyczącej etyki i moralności spotkania, uznanych wartości, postawy dialogicznej, poczucia sensu życia.

Koncentracja uwagi badawczej w zakresie funkcjonowania seniorki doświadczonej chorobą nowotworową w wieku 70 lat stanowiła punkt zwrotny do tego, co było „przed”, a tym, co było „po” nabyciu statusu „pacjenta onkologicznego”. Znalezienie się w sytuacji ,podwójnej tożsamości” stanowi etap przekraczania granicy sprawności i oswajania aktualnego obrazu siebie, kształtowanego przez grupy odniesienia (Kępiński, 1998). Analiza w głąb pozwala odkrywać własne miejsce w zastanej egzystencji oraz znaczenie walki w niej o siebie. 
Przekraczanie granicy zdrowia nie dzieje się z dnia na dzień, stanowi proces, w którym zdobywamy wiedzę o sobie, innych... Owa wiedza to pozornie wiedza „zbędna”, w pewnym sensie nieformalna, bo postrzegana przez pryzmat niewiary w fakt choroby, przyswajana niejako przez przypadek w zderzeniu z niewiadomą, inną rzeczywistością, „[...] jest to taki rodzaj wiedzy, której nie można się nauczyć. Jej istotą jest to, że musimy ją odkryć sami” (Rogers, 2002, s. 253); „[...] bycie i działanie wydaje się być ważniejsze dla tożsamości jednostki niż przekonania i założenia" (Dominicé, 2000, s. 127).

Jednak ryzykownym byłoby stwierdzenie, że kobieta umiejscowiona w nagłym chaosie i nieprzewidywalności zdarzeń zdobywa wiedzę o sobie. Rzeczywistość akceptowana bez zastrzeżeń jest przestrzenią ograniczoną, poza którą rozciąga się horyzont nieokreślonego. W sytuacji traumy zmianie może ulec struktura czasowa i przestrzenna. Nowy profil temporalny, który często towarzyszy traumie społecznej, wymusza dostosowanie indywidualnego czasu przeżywanego; rozszerzeniu nierzadko ulega także struktura przestrzenna życia, np. kiedy sytuacja wymaga poszerzenia pola uwagi dla uchwycenia przyczyn doświadczanych zdarzeń.

Podmiot w swych codziennych doświadczeniach kieruje się przede wszystkim motywem pragmatycznym, który określa perspektywę bezpośredniego zainteresowania. F. Schütze (2006, s. 877) pisze, że orientacja w rzeczywistości opiera się m.in. na idealizacji, którą autor określa formułą: „mogę to zrobić powtórnie”; myśl taka implikuje założenie przewidywalnej rzeczywistości oraz powtarzalności pewnych zjawisk.

Problem zaczyna się w momencie, w którym rzeczywistość stawia opór poprzez nieprzewidywalną zmianę sytuacji. Co prawda, zasób wiedzy jest na tyle rozległy, że pozwala na dostosowanie się zachowań podmiotu do zmieniającego się kontekstu, jednak w czasie radykalnej, głębokiej zmiany-traumy ów zasób wiedzy staje się niewystarczający.

Fakt spotkania w czasie i przestrzeni z jednej strony odnosi się do dziejącej się tu i teraz rzeczywistości. Interakcja między podmiotami zaś sprowadza się do ułatwiania zrozumienia innego, pozytywnego rozwiązania konfliktu i nierównowagi, prowadzącego do nowego spojrzenia na rzeczywistość. Z drugiej strony oscyluje wokół potencjalności moralności spotkania, które w odczuciu podmiotu jest „inne” niż to, które istnieje w chęciach czy świadomości działającego.

W normalnych warunkach działania oparte na przedrefleksyjnych założeniach zapewniają trwałość interakcji czy swego rodzaju homeostazę podmiotowego funkcjonowania. Jednak sytuacja diametralnie się zmienia wraz z pojawieniem się nadsytuacyjności. Traumatogenna zmiana bez wysiłku może wpływać na fakt dotychczasowej oczywistości spotkania. Doświadczenie graniczne prowadzi do blokowania perspektyw sprzyjających przyjmowaniu intersubiektywnej bezpiecznej wiedzy.

Złośliwa choroba nowotworowa weryfikuje wielość więzi społecznych, niespodziewanie współtworząc nowe. Jakość takich doświadczeń ponownie inte- 
gruje człowieka z jego „byciem” w sieci aktualnych relacji społecznych. Stan przewlekły znacząco uwrażliwia na relatywność i umowność układów i struktur społecznych. Takie wejście w jakościowy wymiar własnej biografii, podbudowane odkryciem wsparcia, kształtuje nową osobowość społeczną człowieka. Kryzys spotkania mógłby zostać przezwyciężony z chwilą przekroczenia granicy między poczynaniami o charakterze intencjonalnym a poczynaniami uwarunkowanymi zrozumieniem (Prawda, 1984, s. 87).

Teza, że „w kontekście procesów biograficznych obok intencjonalnych form aktywności konstytuujących działanie społeczne, istnieją formy aktywności i doświadczenia uwarunkowane i sterowane zewnętrznie" (ibidem, s. 84) odpowiada sekwencjom biograficznym, w których jednostka ukierunkowana jest na realizację oczekiwań społecznych wynikających z jej wieku, statusu społecznego, pełnionych ról społecznych bądź zawodowych (por. Schütze, 1997, s. 29).

Potencjał trajektorii wyzwala się pod wpływem zdarzenia/sytuacji, a jego procesualność powoduje wyzwalanie lęku, niepewności, poczucia zależności od innych znaczących. Trajektorie odpowiadają ,zasadzie bycia ogarniętym przez zewnętrzne, niezależne od własnej kontroli okoliczności i wydarzenia, czyli sytuacje biograficzne, w których jednostka znajduje się pod wpływem sił zewnętrznych, niezależnych od jej intencji, powodujących progresywne kurczenie się możliwości jej swobodnego działania" (Rokuszewska-Pawełek, 1996, s. 44). Trajektoria stoi w opozycji do biograficznego schematu działania i pojmowana jest jako „bezładne procesy społeczne i procesy cierpienia” (Riemann, Schütze, 1992, s. 92). Choroba nowotworowa powoduje, iż „dalekosiężny biograficzny schemat działania zostaje przerwany i zniekształcony przez bardzo silną i niszczącą zasadę biograficznej trajektorii" (ibidem, s. 98).

Śledzenie ścieżek prawdziwego realizmu, który stał się kierunkiem własnych zamierzeń badawczych oraz zainteresowanie nowym ukonkretnionym do szczegółu ludzkiego realizmem jest zarazem wydobyciem na światło „najcichszego" z ludzkich głosów, wydobyciem strzępków egzystencji, prawdziwej, najsłabszej, najbiedniejszej i „mizernie” prostolinijnej, jest drążącym oporem wobec „psychologicznych manier” członków relacji. Nowy realizm, oparty na „zdarzeniach mentalnych”, „dotknięciach materii”, „dotknięciach egzystencji” i ich uporczywym „przypominaniu” (Lupa, 2003, s. 362) jest doświadczaniem progów granicznych. Autentycznych zagrożeń wymagających autentycznej czujności (ibidem), czujności wobec prawdy jednostkowego życia i konstytuujących go dynamizmów psychicznych. Jak wynurzyć z głębokości ów proces? Refleksja pedagogiczna wzbogaciłaby się, gdyby mogła zyskać „,dobrze nastrojoną, autentyczną czujność rozszerzającą się na całej przestrzeni” (ibidem), udrażniającą drogi między fragmentami wiedzy, nowego czucia świata, nowego wirusa prawdy (ibidem), stanowiłaby zwrot ku postrzępionej, fragmentarycznej, symptomatologicznej egzystencji/refleksji pedagogicznej jako niezwykle wartościowej płaszczyzny myślenia. 
Uzyskane dane pochodzące z biografii potraktowałam jako źródło subiektywnego odtwarzania doświadczeń, przeżyć seniorki obarczonej chorobą terminalną. Owo subiektywne odtwarzanie traktuję jako jedyną realną prezentację (Urbaniak-Zając, 2011, s. 20). Prezentacja wyników sprowadza się do wyodrębnienia tematów wynikających z wypowiedzi badanej, obserwacji uczestniczącej/parafrazy wypowiedzi seniorki (fenomenologia przeżyć i doświadczeń, filozofia świadomości). Wychodzę z założenia, że koncentrowanie się wyłącznie na języku nie odda w pełni sensu i znaczenia eksplorowanej perspektywy biograficznej. Przedmiotem zainteresowania są wybrane zdarzenia biograficzne, istotne, rzeczywiste momenty (Mandes, 2012, s. 30) przebiegu choroby kobiety w aspekcie identyfikacji uwarunkowań postaw decydentów. Opis funkcjonowania, chęć zrozumienia zastanej rzeczywistości chorej odnoszą się do podejścia etycznego, sprowadzającego się do reprezentacji sprawstwa członków rodziny, opiekunów, lekarzy, pielęgniarek. Jak pisze A. Wejland (2011, s. 16) ,wytyczony, czyli mający swoje granice horyzont jest więc sposobem ogarniania przez nas rzeczywistości, sposobem jej konceptualizacji, zależnym od tego, jak nasze pole widzenia określane jest przez miejsce, w którym się znajdujemy i z którego patrzymy, a więc przez nasz punkt widzenia. Ujęcie to oprócz ograniczoności horyzontu zakłada wszak także możliwość jego zmiany wraz z przesuwaniem się locus standi-punktu, który jest ucieleśnieniem nas samych w wyobrażonej, podpowiadanej metaforą, przestrzeni wiedzy i zainteresowań poznawczych”.

\section{Pamiętam taki dzień Szliśmy razem trzymając się za ręce Słońce z nieboskłonu wlewało w nas szczęście I słychać było muzykę naszego życia}

Spotkanie jako realne, możliwe, przemieniające ludzkie życie stanowi swego rodzaju łaskę, a świadomość tego jest bardziej dojmująca, im więcej mamy możliwości nawiązania kontaktu. Tylko autentyczne spotkanie pozwala przezwyciężyć samotność... (Gadacz, 2003, s. 110). Każdorazowe doświadczanie spotkań z mamą otwierało nowe horyzonty, uskrzydlało, dawało siłę do zmagań codzienności. Autentyczność owych spotkań pozwalała na wyłączenie się z biegu funkcjonowania, wyciszenie i wyrażanie własnych przeżyć.

Wielkoduszność kobiety wobec członków rodziny zacieśniała między nimi silną więź emocjonalną. Jej umiejętność odkrywania i uchwycenia tego, co istotne w życiu, odwaga, poświęcenie sprawiały, że rolę matki, żony wypełniała w pełni odpowiedzialnie, oddanie i konsekwentnie. Celem w jej życiu było zapewnienie startu w dorosłość swych dzieci, pomoc, czujność i wielowymiarowe zaangażowanie w ich rzeczywistą przestrzeń. 


\section{Pamiętam taki dzień \\ Kiedy deszcz dzwonił o szyby \\ Przyjaciel nie był przyjacielem \\ W sercu samotność zabrała nadzieje}

Wczesne objawy chorobowe i prywatne wizyty u specjalisty z zakresu reumatologii wskazywały na prawdopodobieństwo dolegliwości reumatoidalnych. Pacjentka była zobligowana do regularnych kontrolnych wizyt w poradni reumatologii w celu stabilizowania ewentualnego bólu. Postawa, relacje lekarki i pacjentki sprawiały, że waga problemu chorobowego nie została zauważona przez pacjentkę i jej rodzinę, wskazywały natomiast na możliwość ewentualnego „wyjścia" z obecnego stanu dolegliwości. Dwuletnią terapię stanowiło przyjmowanie przez pacjentkę określonych dawek leków sterydowych. Jednak niepojący, pojawiający się coraz częściej stan wysokiej gorączki nie pozostawiał złudzeń, że kobieta potrzebuje natychmiastowej diagnozy i konsultacji.

Początkowy stan zadowolenia z możliwości skorzystania z wizyty u znanego profesora, specjalisty chorób wewnętrznych, niemalże przy pierwszym badaniu ujawnił jego niski poziom inteligencji terapeutycznej. Profesor traktował wizytę szablonowo, zadając pacjentce wiele pytań bez możliwości konstruowania narracji przez badaną, wręcz ignorowania jej reakcji - wbrew funkcjonującemu w literaturze przedmiotu (m.in. Heszen-Niejodek, 1992, s. 76) rodzajowi modelu kontaktu lekarz-pacjent określanemu jako obustronne uczestnictwo, zakładającemu nie tylko aktywność, ale i partnerski udział pacjenta. Kompetencje są w tym modelu symetryczne wskutek uznania faktu, że lekarz to ekspert w zakresie medycyny, ale i pacjent jest w pewnym stopniu ekspertem w zakresie indywidualnego przeżywania własnej choroby.

Owa pilotażowa wizyta stanowiła jakby zwiastun celu, sposobów i specyfiki podejmowanej aktywności przez opiekę medyczną, przepowiednię charakteru przyszłych zmagań pacjentki o własne życie.

Kolejne wizyty u profesora miały podobny przebieg - skoncentrowanie się na klinicznych objawach choroby, niezauważanie emocji związanych z chorobą. Taki scenariusz wizyt zwiększał niepokój pacjentki i poczucie niezrozumienia. W kontekście badanej egzystencji, kultury jej opowiadania została ujawniona jedna $\mathrm{z}$ najbardziej efektywnych form komunikacji służącej przekazowi i wymianie dotychczasowego pojmowania, przeżywania świata i sytuacji związanych $\mathrm{z}$ doświadczeniem i sensem funkcjonowania. W kontekście klinicznym narracje pacjentów winny pomagać lekarzowi w zrozumieniu choroby, systemu wartości pacjenta czy własnych celów i ideałów życiowych, stwarzać okazję do rozwoju i przejawiania empatii, prowokować do stawiania pytań i podnoszenia problemów, które w przeciwnym razie mogłyby nigdy nie być zauważone, winny być nośnikiem ważnych informacji, ułatwiających zdiagnozowanie stanu pacjenta, winny 
mieć potencjał terapeutyczny, uruchamiać efekt placebo, stanowiąc szczególną pomoc w sytuacji chorób chronicznych. Ową sytuację wnikliwie charakteryzuje I. Heszen-Niejodek (por. ibidem, s. 188-189), wskazując na istotę konfrontacji pacjent-lekarz, podmiotowej regulacji funkcjonowania człowieka. Stwierdza, że ważne znaczenie dla kontynuacji, zaprzestania lub modyfikacji czynności ukierunkowanych na cele zdrowotne ma ocena pacjenta, dotycząca efektów dotychczasowego leczenia (ibidem, s. 189).

Dotychczasowe wizyty znajomych ograniczały się do ich znikomej liczby. Po diagnozie, w świadomości koleżanek chorej funkcjonował stereotyp ewentualnych konsekwencji chorobowych dla nich samych. Niechętne, krótkie, wręcz wymuszone odwiedziny wskazywały na problematyczność dalszych spotkań z chorą, które to aspekty znacząco wpływały na samopoczucie kobiety. Widok, świadomość sytuacji, w której znajomi niekoniecznie okazują się znajomymi, nie są tak blisko, jak można by oczekiwać, czy wyobrazić. Towarzyszenie człowiekowi w jego cierpieniu wymaga poznania go jako człowieka oraz głębokiej samoświadomości własnych zasobów i deficytów. Zdaniem M. Kosowicz (2010, s. 259) przekonania, wartości, utrwalone schematy myślowe, zgodnie z którymi żyjemy, stanowią swego rodzaju indywidualną pamięć, oczekiwania, przekonania, doświadczenia i niepokoje, ,schematy mogą być źródłem cierpienia, gdyż dostosowując się do nich, rozmijamy się z prawdą i kreujemy świat zdominowany przez pragnienie i strach" (Lewine, 1996, s. 60). Chora, pomimo osobliwego poczucia zawstydzenia, natychmiast wyczuwała ich dystans sygnalizujący granice współodczuwania.

\section{Powiedziałaś nie walcz ze złem świata Bądź tu i teraz}

Po kilku wizytach i zaleconym stosowaniu leków w silnej dawce, stan pacjentki uległ pogorszeniu, nastąpiła więc decyzja u umieszczeniu badanej w klinice MSWiA w Warszawie w celu diagnozy zaistniałych objawów. Po wielokrotnych badaniach, którym została poddana na kilku oddziałach, wykryto zmiany nowotworowe. Jeden z zabiegów obejmował diagnozę węzłów chłonnych, przebiegał przy użyciu narkozy. W krótkim odstępie czasu dokonano dwukrotnej, wyczerpującej ingerencji chirurgicznej w zakresie zmian nowotworowych. Zlecono chemioterapię. Wizyty w poradni chemioterapii oscylowały wokół 10 minutowego spotkania specjalisty z członkiem rodziny. Natomiast pozycja chorej ograniczała się do wyczekania końca bezosobowej konfrontacji. Odczucie chorej sytuujące się w ograniczaniu jej podmiotowości potęgowało biurokratyczne, formalne podejście ze strony lekarza, przerywane prowadzonymi przez niego rozmowami telefonicznymi czy notorycznym przerywaniem wizyty przez wchodzące pielęgniarki, rejestratorki. Kontakt z chemioterapeutą nie pozostawiał złudzeń, co do 
dalszego przebiegu leczenia. Początkowo chora została umieszczona na oddziale chemioterapii w celu ustalenia specyfiki dalszego leczenia. Jej niepokojący stan zdrowia prowokował członków rodziny do stałej obecności przy niej. Rodzina naprzemiennie zmieniała się w czuwaniu przy chorej, aby ów pobyt był w jak najmniejszym stopniu przykry. Jednak przebieg diagnozy na oddziale wydłużał się na tyle, że przy okazji wyczekiwania na czczo na poranne badanie TK, rodzina zwróciła się do lekarza dyżurnego z prośbą o udzielenie informacji o przyczynie tegoż opóźnienia. Reakcja lekarza stanowiła „wulkan emocjonalności”. Ekstrawertyczna postawa medyka skutkowała w konsekwencjach niesprzyjających dalszemu pobytowi pacjentki na oddziale, z powodu wyrzutów czynionych jej przez inne osoby z personelu jak też otrzymania telefonu przez córkę od ordynatora oddziału, w którym to zastrzegł sobie indywidualną rozmowę w celu oceny „występku” rodziny. Rozbieżność między samooceną a standardami osobistymi ordynatora określała jego oczekiwania wobec rodziny pacjentki - oczekiwał przeprosin, zagroził wypisem w trybie natychmiastowym z oddziału. Sytuacja i stres nie pozostawiły obojętną samej chorej. Być może ten czynnik emocjonalny spowodował silne napięcie psychiczne mogące się przyczynić do uaktywnienia silnego napięcia fizjologicznego (Terelak, 2001, s. 323-327). W pewnym zakresie skupienie uwagi tylko na chorobie pacjentki spowodowało swego rodzaju doświadczenie uprzedmiotawiające. Deficyt w sferze autentycznego spotkania z drugą osobą, angażujące holistyczne ja, niezbędne do doświadczania własnej inności/oryginalności.

Gdzie istnieją granice pokory, a gdzie absurdu?

Choroba przewlekła dla jednych stanowi drogę duchowego rozwoju, dla innych traumę, z której trudno się podnieść. Jednak zawsze pozostaje nauką cierpliwości, zaufania własnym siłom.

Każda postać oddziaływań człowieka wobec człowieka, w tym oddziaływań o charakterze pomocowym, w tej samej mierze posiada specyficzne konteksty antropologiczno-aksjologiczne oraz etyczne (Ricken, 2001, s. 5).

Chęć lub potrzeba niesienia pomocy innym w swej idealistycznej postaci czerpie podstawowe impulsy z wrażliwości na drugiego człowieka i ludzkie losy oraz zdolności do empatycznego wczucia się w indywidualne trajektorie biografii człowieka, który staje się potencjalnym adresatem działań pomocowych służby zdrowia (Pytka, 1998, s. 386). Określona strategia działania lekarza stanowi wyraz afirmowania bądź deprecjonowania podmiotowości chorego, wymuszając określone racje etyczne, zwrócenie uwagi na problemy etyczne ujawnia wymiar możliwości rozwiązywania istotnych kwestii wywierających wpływ na jakość i sens życia chorych tylko przez istoty czujące (por. Goldstein, 1994, s. 71).

Rodzina rozważała ewentualność złożenia zażalenia do Komisji Etyki Lekarskiej, jednak zważywszy na stan chorej zaniechała tego zamysłu. Rdzeń etyki lekarskiej stanowią dyrektywy elementarne i ogólnoludzkie. Te właśnie reguły 
są trwałymi elementami etyki zawodu jak też decyzje podejmowane przez lekarzy z punktu widzenia dobra człowieka, jego życia i zdrowia, które stają się naczelnymi wartościami generującymi postawy etyczne i inne działania w obrębie tego zawodu (Maroszyńska-Jeżowska, 2004). Prawda subiektywna w medycynie współczesnej wynika z ujęcia natury człowieka, w oparciu o którą można przeprowadzić racjonalną analizę zjawisk etycznych wpływających pozytywnie na jakość praktyki lekarskiej. Zgoda co do tego, że celem medycyny jest walka z chorobą i zachowanie zdrowia wymaga uwzględnienia kontekstu subiektywnego, a więc zauważenia autonomii pacjenta, rozwiązywania określonych konfliktów moralnych (Maroszyńska-Jeżowska, 1998, s. 21). Element wartościujący, sytuujący się w określeniu stanu zdrowia pacjenta winien wskazywać na fakt traktowania człowieka jako istoty świadomej swej tożsamości. Obserwacja w realności medycznej wskazuje, że zmiany w systemie wartości, niedoskonałość filozofii i ich konsekwencje w życiu osłabiają osobową tożsamość człowieka.

Najbardziej uderzający wniosek z owych zdarzeń może wskazywać na strategiczną właściwość zachowania lekarza jako środka oddziaływania na zachowanie pacjenta w pożądanym kierunku - obrona własnej pozycji i odreagowanie negatywnych emocji. Frustracja lekarza wywołuje poczucie osobistego zagrożenia i pobudza do zachowań ukierunkowanych na obronę ego. Napięcie powstałe w obszarze społeczno-emocjonalnym odsuwa na plan dalszy realizację zadania/leczenia, co potwierdzają wyniki badań prowadzone pod kierunkiem I. Heszen-Niejodek (1992).

W optyce zastanej sytuacji pozycja autorytetu, przytłaczanie pacjenta niekontrolowaną reakcją emocjonalną, perswazja niepozostawiająca wyboru i taktyki osobiste/groźby, wyolbrzymianie negatywnych skutków postępowania pacjenta, wywołują lęk lub potęgują już istniejący, mogą wywołać niekorzystne zmiany w płaszczyźnie społeczno-emocjonalnej, jak pogorszenie stanu emocjonalnego pacjenta i dysonans spotkania (ibidem).

Dominujący relatywizm w czasach zmian kulturowych odznacza się dramatycznym rozpadem jednorodności, liniowości i stabilności (Jaworska-Witkowska, Kwieciński, 2011, s. 106-107). Ze strony opieki medycznej zabrakło przełożenia pełni człowieczeństwa na ochronę słabszego, z zapewnieniem godności egzystencji chorej (zob. Andrzejewski, 2010, s. 350).

\section{Spojrzałem w nieboskłon z nadzieją Że wszystko co dane jest od Ciebie Pozwala pokonać zło}

Przekonanie pacjentki, że określone działania ludzkie da się zrozumieć, niejako zachęcało ją do trwania i przywracało wiarę we własne siły. Można więc pokusić się o stwierdzenie, że odporność na stres zależy od postawy życiowej, umiejętności walki ze stresem oraz afirmacji, która sprzyja znoszeniu blokad 
w zaspokajaniu potrzeb i realizowaniu celów. Do istotnych zasobów w procesie radzenia sobie ze środowiskowymi stresorami zalicza się indywidualne, relatywnie stałe właściwości jednostki określane mianem przekonań i oczekiwań (poczucie koherencji, własnej wartości, poczucie panowania nad zdarzeniami).

Aby być profesjonalistą skutecznie zarządzającym potencjałem „inności”, trzeba wręcz wywołać własne doświadczenia owej ,inności”, nauczyć się komunikacji z „obcością” poprzez własne odkrycie „bycia obcym”. Wraz z pojawieniem się ,innego"/,obcego" przedrefleksyjne bycie zapewniające homeostazę interakcji zmienia się nie tylko z faktu posługiwania się przez ,innego" różnymi typifikacjami, ale wymiaru zmiany traumatogennej, wynikającej ze swego rodzaju niewiadomej, naruszającej/kwestionującej dotychczasowe poczucie bezpieczeństwa kobiety.

\section{Zło świata znów zwyciężyło Stanęłaś w drzwiach spojrzałaś na mnie sercem Twoje słowa niczego nie wypowiedziały}

Specjalista wyznaczył cykl sześciu sesji. Każda sesja wiązała się z długim oczekiwaniem na szpitalnym korytarzu. Dodatkowe dolegliwości pacjentki „dawały o sobie znać” w postaci silnego bólu kręgosłupa, osłabienia. Po przyjęciu chemii, wyczerpana wracała do domu. Pozostałość pooperacyjna w postaci przepukliny uniemożliwiała normalne funkcjonowanie. Na owym etapie życia dochodziło do jawnych aktów dyskryminacji starszego człowieka i fundamentalnych zasad bioetycznych. Radykalizm w przedmiotowym traktowaniu pacjenta przez opiekę medyczną oparty na posłuszeństwie, przymusie w kwestii niemożności usunięcia przepukliny prowadził do narastania nierówności w interakcji lekarzpacjent. Specjaliści chirurdzy ograniczali się tylko do wykonywania wyuczonego zawodu, postępowania ,zgodnego ze sztuką", polegającego na rutynie, co w pewnym zakresie powodowało dewaluowanie motywu wyzdrowienia u pacjentki czy dostarczenia jej wiary i ulgi w obecnym funkcjonowaniu. $Z$ naturalnej postawy pacjentki wynikała troska o jakość życia nie tylko w wymiarze fizycznego nieodczuwania bólu, ale utrzymanie psychicznej sprawności jako samoświadome decydowanie o sobie i uczestniczenie w życiu. Owej troski o utrzymanie jakości własnego życia nie można ujmować poza kontekstem dialogicznego spotkania (Kaczkowski, 2011, s. 286-302). Po kilku wizytach chirurgicznych, z pomocą pracownika hospicjum domowego Caritas oraz permanentnego występowania deficytów wynikających z wciąż powiększającej się przepukliny, zdecydowano się na jej usunięcie. Po bolesnym zabiegu usunięcia przepukliny i pobycie pacjentki w szpitalu wystąpiło powikłanie w postaci puchnięcia nogi. Mimo sugestii rodziny, chora została wypisana z oddziału chirurgii onkologicznej z zaleceniami farmakologicznymi. 
W trakcie owych doświadczeń pacjentka przez sześć miesięcy była poddawana chemioterapii. Pomimo negatywnej tolerancji chemii, uczestniczka moich badań wykreowała nową jakość swego istnienia, niejednokrotnie przekraczając własne ograniczenia swojej choroby. Badana wykraczała „poza” czas swojej egzystencji, który mógł być w jej biografii znacznie krótszy albo w innej jakości; wykraczała „poza” ograniczenia schorowanego organizmu, potrafiąc funkcjonować w swojej codzienności, tworząc nowe perspektywy na przyszłość, pragnąc spełniać się w nowej „postaci”. Owe przesłanki stanowią elementy humanizmu transgresyjnego i postawy homo transgressivus.

Przez około rok badana nie wykazywała objawów nawrotu choroby. W międzyczasie jednak na skutek przyjmowania sterydów nastąpiły kompresyjne złamania kręgosłupa, które to wiązały się z kolejnymi pobytami w szpitalu. Pacjentka przebywała dwa tygodnie na oddziale ortopedycznym bez kontaktu z lekarzem prowadzącym. Ostatecznie, terapeutycznie zlecono gorset jewetta, który nie spełnił żadnych kryteriów specjalistycznych w zakresie funkcji, gdyż był zbyt obciążający jak na tak słaby organizm. W dniu wypisu lekarz prowadzący udzielił chorej porady zażywania raz w miesiącu jednej tabletki zapobiegającej procesowi osteoporozy. Inną kwestię stanowiła decyzja o odstąpieniu od ewentualnego zabiegu operacyjnego, celem którego miałoby być wzmocnienie kręgosłupa (argumenty to: zaawansowany wiek i zbyt zaawansowane zmiany). I znów powtórka scenariusza:... konspiracyjne przekazywanie informacji przez lekarza, budowanie nadziei na fałszywych przesłankach...

\section{Dziś wszedłem do Twego pokoju \\ Otworzyłaś na chwilę oczy Spojrzałem w okno \\ Słońce ostatnim promieniem Kreśliło na ścianie znak}

Cierpienie chorej zdawało się pogłębiać poprzez nawrót choroby nowotworowej.

Wystąpienie pierwszego napadu padaczkowego świadczącego o przerzutach do mózgu już na zawsze zmieniło życie kobiety i najbliższych.

Wizja stanu seniorki przeraziła domowników. W pogotowiu kobieta bardzo narzekała na ból głowy, na którą to reakcję ratownicy medyczni zareagowali w sposób wykraczający poza granice kompetencji i etyki. Krótki przekaz medyków - „nic nie poradzimy, że ma pani guza w mózgu” - zaprzepaścił wiarę w harmonijny, spokojny wymiar zdrowienia, wyznaczał natomiast konieczność wytrwałego trudu i bezkompromisowej walki z chorobą. Pod wpływem tego silnego wydarzenia pacjentka pozostała poruszona i ugruntowana w postawie niweczącej wszelkie specjalistyczne działania względem jej. 
Rzeczywistość zastana po przewiezieniu kobiety do szpitala na oddział neurologii wymusiła u najbliższych redefinicję funkcjonowania opieki medycznej oferowanej chorej w sytuacji diametralnej zmiany dotychczasowego jej egzystowania. Na ogół szpital winien zabezpieczać potrzebę bezpieczeństwa pacjenta i względnego komfortu fizycznego i nade wszystko psychicznego (Walden-Gałuszko, 1992, s. 19). Realizacja owych potrzeb w wielowymiarowej płaszczyźnie została zablokowana, gdyż obraz, jaki zastała córka, przekraczał jej wyobrażenie w kwestii postaw medyków winnych zaświadczać o człowieczeństwie. Kobieta była przywiązana zwykłymi bandażami do łóżka w sposób absolutnie krępujący jej jakikolwiek ruch. Próba poruszenia ręką powodowała naciąganie bandaża w okolicy pachwin, co sprawiało niewspółmierny ból, w szczególności jeśli wziąć pod uwagę całonocną, tę samą pozycję ułożenia kobiety. Kadra medyczna argumentowała tę sytuację nadmiernym pobudzeniem chorej i chęcią opuszczenia oddziału, a przy braku specyfikacji psychiatrycznej oddziału techniki ograniczania rzekomo ewentualnych „naddziałań” pacjentów pozostawiają wiele do życzenia. Spotkanie na ów moment spotęgowało już na trwałe stan wyczulenia, ostrożności, ,naduwagi” najbliższych na wymiar rozumienia kolejnych odsłon jakości oddziaływań wobec chorej. Wbrew przypuszczeniom zespołu medycznego, chora pamiętała minioną noc, opowiadając córce szczegóły jej przebiegu. Radykalnie zatrzymany czas w świadomości córki, powodował uruchamianie naprzemiennie mechanizmów gotowości i siły oraz paraliżującego przerażenia. Pobyt na oddziale skutkował szczegółową diagnozą stanu pacjentki przez specjalistę prowadzącego. Po upływie dziesięciu dni chora została wypisana do domu z zaleceniami natychmiastowej konsultacji z prowadzącą chemioterapeutką $\mathrm{w}$ celu ustalenia dalszych etapów terapii.

Po pilnych wizytach u chemioterapeuty, na skutek występujących objawów zalecono radioterapię. Poruszeniom nie było jednak końca.

Pewnego wieczoru córka pomagała mamie dojść z łazienki do łóżka. Po dotarciu do pokoju, w którym najczęściej przebywała mama, mając zaledwie dwa metry do łóżka gwałtownie upadła przez dysfunkcję nogi. Uderzenie było na tyle silne, że nie można było podnieść kobiety we dwoje bez swego rodzaju stelaża nienaruszającego żadnej części ciała. Po przewiezieniu kobiety do szpitalnego oddziału ratunkowego stwierdzono po badaniu, że najprawdopodobniej osłabiony kręgosłup uległ kolejnym złamaniom. Ból narastał, a pacjentka czekała na decyzję, co do dalszej formy hospitalizacji w izbie przyjęć. Wzmożony ruch personelu medycznego i przybywających pacjentów powodował odczucie dyskomfortu tak dla chorej, jak i najbliższych. Córka z mężem zgodnie z dyspozycją lekarza oczekiwali na informacje na korytarzu szpitalnym. Biorąc pod uwagę stan kobiety, czyli fazowe odzyskiwanie świadomości, owa konieczność wyczekiwania bez kontaktu z mamą wydawała się nie mieć końca. Około drugiej w nocy lekarz dyżurny zasugerował opuszczenie izby przyjęć przez rodzinę, gdyż chora pozostanie na oddziale do rana w celu przeprowadzenia dogłębniejszych badań, 
a następnie przetransportowana do domu. Rano córka przeprowadziła rozmowę telefoniczną z przełożoną pielęgniarek dotyczącą uściślenia czasowego przywiezienia kobiety. Z zapewnień wynikało, że karta wypisu z oddziału jest przygotowana, więc właściwie zaraz zostanie odwieziona. Kwestia czasowości była tym bardziej istotna, że o stałych porach chora przyjmowała leki i miała zmieniane plastry przeciwbólowe. Po około godzinie od rozmowy z przełożoną zaniepokojona córka ponownie zadzwoniła do szpitala i ku zaskoczeniu otrzymała informację o przewiezieniu mamy do domu, z tym, że przy wypisie odniesiono się do danych dowodu osobistego, a nie do danych przyjęciowych na oddział. Kobieta została przetransportowana do miejscowości, w której do momentu nasilenia się objawów choroby mieszkała. Zaskoczenie męża było tym większe, że nie był przygotowany na przyjazd żony, a tym bardziej sprawowania specjalistycznej opieki nad nią. Po natychmiastowej interwencji personelu karetka zawróciła do miejsca docelowego. Była godzina trzynasta, kobieta zmarznięta, wyczerpana dotarła do domu.

Wydawałoby się, że postawa lekarza winna być skierowana ku człowiekowi choremu, wykazywać altruizm czy gotowość do przekształcania idei kompetencyjności w aktywność, odróżniania głębi od pozoru. Zawód lekarza można określić jako przywilej zaufania, który nadaje lekarzowi społeczeństwo (Słomski, 2008, s. 79). Etyka lekarska nie tylko formułuje zasady relacji lekarz-pacjent, lekarz-rodzina pacjenta, lekarz-firma farmaceutyczna (ibidem, s. 11), ale także określa sposoby rozwiązywania dylematów moralnych dotyczących funkcjonowania w roli lekarza (np. konflikt pomiędzy zdrowiem pacjenta a prawem pacjenta do decydowania o samym sobie) (ibidem, s. 35).

Umieszczenie chorej na oddziale radioterapii poprzedziły niespodziewane okoliczności. Kolejny silny atak padaczkowy i towarzyszące mu objawy, czyli utrata świadomości, silne wstrząsy, a następnie majaczenie i agresywność, sprawiały, że opiekująca się córka natychmiast wzywała pogotowie w celu złagodzenia przykrych doznań i cierpień mamy. Nagłość ataku, jego widok i świadomość konsekwencji paraliżował wszelkie próby racjonalnego odnajdywania się bliskich. Przyjazd pogotowia wiązał się z kolejnymi przykrymi doświadczeniami. Lekarz pogotowia i ratownik medyczny wciąż podejmowali próby uświadamiania członkom rodziny o jej bezprzedmiotowym działaniu wobec opieki medycznej w przypadku chorej z nowotworem rozsianym. Standardowe podejście do zastanego przypadku (morfina) skutkowało długim stanem pobudzenia kobiety ze współwystępującymi reakcjami agresji i majaczenia. Czuwanie nad chorą wydawało się nie mieć końca ani przerw. Natłok wydarzeń w horyzoncie zastanej rzeczywistości i konfrontacja z nią ukierunkowywała bliskich na przekraczanie i czynienie siebie odważniejszymi.

Ostatecznie kobieta trafiła do szpitala i po kilku dniach neurolog poinformował córkę, że winna ona zabrać mamę z oddziału do domu, która to informacja nie stanowiła sensownego rozwiązania. W stanie cielesnej bezładności, problemami 
z chodzeniem, ogólnym osłabieniem i w stanie psychicznego rozbicia chora miała być wypisana z oddziału na jeden dzień, w kolejnym natomiast miała stawić się na oddział radioterapii. Zderzenie z argumentacją lekarki usytuowało córkę w bezpośredniości w stosunku do niej i przekonaniu jej o konieczności pozostawienia mamy na oddziale. Rozmowy z neurologiem zaowocowały uniknięciem niewyobrażalnego niebezpieczeństwa wyprawy na jedną noc do domu z chorą kobietą.

Zabieg lekarski, jaki miał miejsce w dniu wypisu i przewiezienia chorej na oddział radioterapii, ponownie zweryfikował sens realizmu medycznego. Wzruszające, dramatyczne i szokujące doświadczenie spotęgowało pogorszenie stanu zdrowia pacjentki z powodu pozostawienia chorej „samej sobie” w obecności syna bez możliwości zaangażowania się personelu medycznego. Po pokonaniu przeszkód i czekając na przyjęcie na oddział, kontakt z chorą został przerwany przez niesprzyjające warunki i czas oczekiwania na miejsce. Taka sytuacja utrzymywała się około dwóch dni. Po czym lekarz dyżurny podczas wieczornego obchodu z naciskiem zakomunikował córce o konieczności przymuszenia chorej do jedzenia. Córka, nie wstrzymując narastającego napięcia, wyartykułowała współodczuwany i współprzeżywany wysiłek przetrwania pobytu w szpitalu. Jednakże wyraźne dystansowanie się lekarza determinowało jego obojętność. Specjalista nie zadbał o atmosferę życzliwego zainteresowania, mimo uwagi, podobnych pragnień zdrowienia i opieki, przychylnych nastawień bliskich chorej. W kontakcie lekarza z chorą zabrakło staranności, swoistej poetyki spotkania. Jednakże pobyt na oddziale radioterapii pacjentki wzbudził nadzieję na osiągnięcie efektu usunięcia guzów w mózgu.

Niebezpieczne i jednocześnie silnie obciążające najbliższych działania sytuowały się w braku koordynacji działań medycznych lekarzy specjalistów. Niestety, po pilnej wizycie u neurochirurga i przeprowadzeniu rezonansu magnetycznego okazało się, że guzy nie zostały usunięte w wyniku radioterapii mimo wcześniejszych zapewnień chemioterapeuty, po przeprowadzonym badaniu TK. A wręcz pojawiło się ich znacznie więcej. Docenienie życia, godności, odrębności praw człowieka oraz powiązań z aksjologicznymi założeniami moralności uniwersalnej obowiązującej wszystkich ludzi winny stanowić o etyce zawodu lekarza, jego autentyczności, profesjonalności, wrażliwości, racjonalności przywracającej poczucie pewności podejmowanych działań, determinujących przestrzenność motywacji.

Chora nie mogła już być poddana zabiegowi neurochirurgicznemu z powodu wielokrotności skupień nowotworowych. Ostatnie zdania, jakie córka była w stanie usłyszeć od neurochirurga po analizie przez niego wyniku rezonansu, zabrzmiały jak wyrok. Natomiast badana podczas konsultacji usłyszała krzepiącą dla niej informację, a mianowicie - brak konieczności ingerencji chirurgicznej mózgu, którą zresztą potraktowała jako kolejną nadzieję. Fakt radosnego przyjęcia decyzji neurochirurga wynikał z ograniczeń percepcji pacjentki - znaczył pokonanie kolejnej przeszkody „w drodze po zdrowie”. Życie pacjentki zaczęło przebiegać jakby we śnie. Stała się zupełnie zmęczona, słaba. 


\section{Powiedziałem: Mamo już wiosna! Twoje słowa niczego nie wypowiedziały Twoje oczy spojrzały na mnie sercem Bądź tu i teraz Nie walcz ze światem}

Nastąpił czas towarzyszenia chorej w jej cierpieniu wymagający głębokiej samoświadomości własnych zasobów najbliższych. Szczególny czas czuwania i uważnego monitorowania zmieniających się reakcji chorej i własnych. Z dnia na dzień córka, jej mąż ugruntowywali się w przekonaniu, że ich zmęczenie wpływa na uważne zrozumienie mamy. 24 godzinna opieka nad seniorką i niedopuszczanie do świadomości własnych słabości i ograniczeń, by wywiązywać się z niej jak najstaranniej, stanowiły priorytet i potrzebę sprostania pewnym stereotypom, własnym oczekiwaniom i oczekiwaniom otoczenia w zakresie wysiłku wobec chorej, nierzadko nie respektując jej potrzeb, własnych ograniczeń i, co najistotniejsze, tracąc najcenniejszy wspólny, pozostały czas.

Wiele sytuacji w opiece nad kobietą powodowało uruchamianie mechanizmów obronnych u najbliższych, jednakże świadomość nieodwracalności choroby mamy nadawała nieprzypadkowy charakter ich relacji. Głęboka wiara córki, że sytuacja nagle się odmieni, że stanie się cud dodawała sił. Uczestnicząc w cierpieniu chorej każdego dnia, najbliżsi doświadczali zintensyfikowanych doznań emocjonalnych. Świadomość jakiejkolwiek stabilizacji ulegała rozproszeniu, bo czas nieubłaganie upływał coraz szybciej. Chora upominała się o opiekę lekarską i kierowała prośbę o pobyt w szpitalu. Wizja lepszej opieki i skuteczniejszego zwalczania bólu, lepszych fizycznych warunków bytowania chorej czy potencjalnej możliwości zapewnienia komfortu ostatniego czasu stanowiły o podjęciu decyzji przez najbliższych o umieszczeniu chorej w oddziale opieki paliatywnej. Złożoność sytuacji/dylematu moralnego kształtowała konieczność dłuższego zastanowienia się nad kryteriami rozstrzygnięć. Trudność z weryfikowaniem docierających do człowieka faktów niejednokrotnie może prowadzić do arbitralności w moralności związanej $\mathrm{z}$ doświadczaniem trudności z uprawomocnianiem podejmowanych wyborów moralnych. Nierzadko więc w obliczu braku uniwersalnych kryteriów decyduje się być arbitrem rozstrzygającym ewentualne dylematy na podstawie indywidualnych kryteriów wartościowania. Problematyczne staje się w takiej sytuacji rozumienie pojęcia odpowiedzialności moralnej. Przyjęcie indywidualnych kryteriów wartościowania działań i sytuacji oraz własnych norm postępowania podważa obiektywne wskaźniki odpowiedzialności za dokonane wybory. Jedynym źródłem kontroli staje się wówczas tzw. instancja wewnętrzna w postaci sumienia, z pominięciem społecznych form kontroli obligujących do uznania i realizowania pewnych reguł (Jaranowski, 2006, s. 19-33). 
Czas pobytu chorej w hospicjum płynął jakby poza nią. Po dwóch dniach córka żałowała tej decyzji. W pierwszym dniu krzepiącym był fakt poczucia pewności seniorki o nieodzownym pobycie w szpitalu. Wykazywała swego rodzaju zadowolenie i pewność miejsca, w którym się znalazła. Już po dwóch dniach sytuacja diametralnie się zmieniła, chora nie mogła samodzielnie wstać z łóżka, mimo podejmowania prób i chęci z jej strony. Pesymistyczny obraz co do dalszego pobytu w hospicjum ugruntowywał córkę w przeświadczeniu o konieczności wycofania się z zaproponowanej przez ową instytucję opieki. Przy przyjęciu pacjenci zostają zacewnikowani, pomimo próśb i zapewnień rodziny o całodniowym pobycie z podopiecznym i dopilnowaniu jego potrzeb.

Zdaniem T. Ślipki (1994, s. 283) „Prawo człowieka do życia rzutuje na pojęcie godności człowieka i jego autotelicznej wartości. Godność człowieka uzewnętrznia się w przysługujących mu prawach. Jeśli zatem nawet podstawowe prawo do życia ma tak kruche korzenie, że ulega zawieszeniu w każdej sytuacji, w której niezależnie od swej woli na skutek nieszczęśliwego zbiegu okoliczności znajdzie się w asymetrycznej mniejszości w stosunku do analogicznych praw innych jednostek, to również osobowa wartość jednostki ludzkiej i reprezentowana przez nią godność ulega radykalnemu zachwianiu".

Obserwacja innych przebywających w sali chorych nie pozostawiała złudzeń, co do finału tegoż pobytu.

Pogłębiający się stan utraty świadomości chorej stanowił cierpienie psychiczne najbliższych, warunkował narastający bunt rodziny wobec zastanej rzeczywistości.

Co uprawnia do twierdzenia, że ból, cierpienie towarzyszące stanowi terminalnemu mogą stanowić duchowe doświadczenie wzbogacające ludzi, skoro są źródłem trwałych zmian, braków konstytuujących destrukcyjną kondycję człowieka i jego godność?

Nie istniało żadne uzasadnienie dalszego pobytu cierpiącej w hospicjum jako alternatywy wobec zwielokrotnionego cierpienia rodziny. Problem opieki nad umierającymi sytuuje się w perspektywie bioetyki, wpisując traumę, tragizm, dramat, ale też nadzieję na być może cudowne rozstrzygnięcie przypisanego losu chorego, znajdującego się w okolicznościach zadających cios w samo sedno człowieczeństwa. Aplikowana chorej morfina powodowała, że po kilku dniach kontakt z chorą był niemożliwy. Skutki, jakie dzięki chemicznym składnikom wywołują środki znieczulające, pozbawiają człowieka zmysłowych reakcji organizmu warunkujących bolesne doznania cierpienia, związane z tymi stanami zmiany organiczne osłabiają siły witalne człowieka (por. ibidem, s. 235).

Najcięższą sytuacją w życiu człowieka jest nieuleczalna choroba, śmierć bliskiej osoby „chociażbyś wytężył swoje wszystkie siły, zmobilizował wszystkie wewnętrzne możliwości, poruszył całą sferę magii, o której działaniu nic nie wiesz poza niejasnymi przeczuciami, mobilizował całą wiedzę - umieranie bliskiej osoby pokazuje ci, że jesteś częścią tej nicości, do której umierający odchodzi” (Szczepański, 1988, s. 249). 


\title{
Więc jestem więc trwam
}

\author{
Mamo, Twoje cierpienie to mój skarb, którym mogę się dzielić z innymi...
}

\section{Literatura}

Andrzejewski P., 2010, Etyczne aspekty praw człowieka, [w:] W. Kaczyńska (red.), O etyce stużb spolecznych, Wydawnictwo UW, Warszawa.

Bukowski J., 1987, Zarys filozofii spotkania, Wydawnictwo Znak, Kraków.

Dominicé P., 2000, Learning from our lives. Using educational biographies with adults, Jossey-Bass, San Francisco.

Gadacz T., 1999, O twarzy innego, [w:] K. Janowska, P. Mucharski (red.), Rozmowy na koniec wie$k u$, t. 3, Wydawnictwo Znak, Kraków.

Gadacz T., 2003, O umiejętności życia, Wydawnictwo Znak, Kraków.

Goldstein H., 1994, Zaniedbane ogniwo moralne w praktyce pracy socjalnej, [w:] M. Bocheńska-Seweryn, K. Frysztacki, K. Kluzowa (red.), Wypisy z wybranych zagadnień pracy socjalnej, Wydawnictwo UJ, Kraków.

Heszen-Niejodek I., 1992, Lekarz i pacjent. Badania psychologiczne, Wydawnictwo Universitas, Kraków.

Jaworska-Witkowska M., Kwieciński Z., 2011, Nurty pedagogiki, Oficyna Wydawnicza Impuls, Kraków, s. 106-107.

Jaranowski M., 2006, Kondycja moralności w epoce przyśpieszenia, [w:] K. Kalka, A. Papuziński (red.), Etyka wobec współczesnych dylematów, Wydawnictwo UKW, Bydgoszcz.

Kępiński A., 1998, Poznanie chorego, Wydawnictwo Państwowy Zakład Wydawnictw Lekarskich, Warszawa.

Kosowicz M., 2010, Psychologiczne aspekty opieki nad umierającymi i ich rodzinami, [w:] M. Górecki (red.), Prawda umierania i tajemnica śmierci, Wydawnictwo Żak, Warszawa.

Levine S., 1996, Kto umiera? Sztuka świadomego życia i świadomego umierania, Wydawnictwo Ewa Korczewska, Warszawa.

Lupa K., 2003, Utopia 2, Wydawnictwo Literackie, Kraków.

Mandes S., 2012, Świat przeżywany w socjologii, Wydawnictwo UW, Warszawa.

Maroszyńska-Jeżowska B., 1998, Relacja pacjent-lekarz w okresie „,paradygmatycznej niestabilności medycyny", t. 4, nr 1, s. 21.

Prawda M., 1989, Biograficzne odtwarzanie rzeczywistości. O koncepcji badań biograficznych Fritza Schütze, „Studia Socjologiczne”, nr 4, s. 81-98.

Pytka L., 1998, O trajektorii cierpienia - kryzys, rozwój, cierpienie, śmierć, [w:] M. Porowski (red.), IPSiR dzisiaj. Księga jubileuszowa, Wydawnictwo UW, IPSiR, Warszawa.

Ricken F., 2001, Etyka ogólna, Wydawnictwo Antyk, Kęty.

Riemann G., Schütze F., 1992, „, Trajektoria” jako podstawowa koncepcja teoretyczna w analizach cierpienia i bezładnych procesów społecznych, „Kultura i Społeczeństwo”, nr 2, s. 89-109.

Rogers C., 2002, O stawaniu się soba. Poglady terapeuty na psychoterapię, Wydawnictwo Dom Wydawniczy REBIS, Poznań.

Rokuszewska-Pawełek A., 1996, Miejsce biografii w socjologii interpretatywnej. Program socjologii biograficznej Fritza Schützego, „ASK. Społeczeństwo. Badania. Metody”, nr 1, s. 37-54.

Schütz A., 2006, Potoczna i naukowa interpretacja ludzkiego działania, „WTS”, t. 2. 
Słomski W., 2008, Dylematy etyki lekarskiej. Zagadnienia wybrane, Wydawnictwo Katedra Filozofii Wyższej Szkoły Finansów i Zarządzania, Warszawa.

Szczepański J., 1988, Sprawy ludzkie, Wydawnictwo „Czytelnik”, Warszawa.

Ślipko T., 1994, Granice życia. Dylematy współczesnej bioetyki, Wydawnictwo WAM, Kraków.

Urbaniak-Zając D., 2011, Biograficzna perspektywa badawcza, [w:] E. Dubas, W. Świtalski, Uczenie się z [własnej] biografii, Wydawnictwo UŁ, Łódź.

Walden-Gałuszko K., 1992, Wybrane zagadnienia psychoonkologii i psychotanatologii. Psychologiczne aspekty choroby nowotworowej, umierania i śmierci, Wydawnictwo UG, Gdańsk

Welland A., 2011, Horyzont-Nawrócenie-Narracja. Tożsamość i obcość w naukowym świecie humanistów, [w:] M. Kafar (red.), Biografie naukowe. Perspektywa transdyscyplinarna, Wydawnictwo UŁ, Łódź.

Włodarczyk R., 2009, Levinas. W strone pedagogiki azylu, Wydawnictwo UW, Warszawa. 